\title{
KEDUDUKAN PEREMPUAN DALAM FIKIH DAN PROBLEMATIKA KEADILAN GENDER
}

\author{
Rosdiana \\ Univesitas Islam Negeri (UIN) Syarif Hidayatullah Jakarta \\ E-mail: ros_sha2009@yahoo.com
}

\begin{abstract}
Abstrak: Tulisan ini bertujuan mengeksplorasi kedudukan perempuan dalam fikih dan problematika gender. Wacana gender secara subtansi bukanlah hal yang baru dalam Islam. Hakikatnya derajat manusia dihadapan Allah sama, maka seyogyanya laki-laki dan perempuan mampu menjalin hubungan kerja sama yang baik tanpa merugikan salah satu pihak. Namun, terjadinya kesan bias gender bagi kedudukan perempuan dalam fikih merupakan akibat dari keragaman opini hukum. Bias gender pun terjadi karena kekeliruan konstruk pemahaman dalam menafsirkan firman Allah dan Hadis Nabi yang kemudian dilegitimasi dengan produk fikih. Untuk itu, reinterpretasi secara kontekstual terhadap setiap dalil yang bias gender mutlak dilakukan. Reinterpretasi tersebut mempertimbangkan kondisi kekinian dan prinsip kemaslahatan bersama, sehingga melahirkan makna dan paradigma baru yang berkeadilan gender serta selaras dengan nilai universal Islam.
\end{abstract}

Kata Kunci: Bias Gender, Fikih dan Reinterpretasi

\section{PENDAHULUAN}

Fikih kaya atas keragaman opini hukum, termasuk fikih perempuan.Opini hukum fikih tentang perempuan tidak tunggal melainkan beragam. Keragaman fikih perempuan ini sejatinya menjadi pilihan alternatif atas fikih yang berperspektif gender.

Di antara penyebab masih adanya pemahaman umat Islam yang bias gender adalah konstruk pemahaman yang keliru dalam menafsirkan firman Allah dan Hadis Nabi yang kemudian dilegitimasi dengan produk fikih. Untuk itu, reinterpretasi secara kontekstual terhadap setiap dalil yang bias gender mutlak dilakukan. Reinterpretasi tersebut mempertimbangkan kondisi kekinian dan prinsip kemaslahatan bersama, sehingga melahirkan makna dan paradigma baru yang berkeadilan gender serta selaras dengan nilai universal Islam.

Ideologi gender memberikan dampak yang signifikan terhadap perkembangan agama, tetapi juga dipengaruhi atau mendapatkan legitimasi dari tafsir agama. Dampak terburuk dari pelegitimasian ini adalah diyakininya perbedaan gender sebagai ketentuan Tuhan atau takdir yang final.Dengan demikian, tidak mudah bagi masyarakat untuk membedakan antara ketentuan Tuhan yang sesungguhnya dengan konstruksi yang dibangun oleh manusia secara sosial. Ideologi gender telah membentuk budaya yang partriarkhal di masyarakat dan menciptakan male-dominated culture, budaya yang didominasi oleh dan mengutamakan laki-laki sehingga memunculkan ketidakadilan.

Salah satu ajaran inti al-Qur'an adalah mengangkat harkat dan martabat manusia sama di hadapan Allah, tanpa mengenal perbedaan jenis kelamin (laki-laki dan perempuan). Yang membedakan keduanya hanyalah kualitas ketakwaannya. Wacana gender secara subtansi bukanlah hal yang baru dalam Islam. Bila dihadapan Allah derajat manusia sama, maka seyogyanya laki-laki dan perempuan mampu 
menjalin hubungan kerja sama yang baik tanpa merugikan salah satu pihak.

\section{PEMBAHASAN}

Pengertian Fikih adalah ilmu tentang hukum-hukum syara' yang bersifat praktis dan digali dari dalil-dalil yang terperinci. ${ }^{1}$ Dikatakan ilmu karena merupakan garapan manusia dengan menggunakan metode-metode tertentu, seperti qiyâs, istihsân, istishhâb, maslahatul mursalah dan sebagainya. Bersifat praktis karena keseluruhan petunjuk dan pedoman hidup beragama, baik dalam kehidupan pribadi maupun sosial, tidakdapat dilepaskan dari panduan fikih. Fikih hampir mendominasi keselurahan kognitif keberagamaan umat Islam. Dengan demikian, hukum-hukum akidah dan akhlak tidak termasuk fikih, karena fikih adalah hukum-hukum syara' yang diambil dari proses istidlâl atau istinbâth dan nazhar (analisis) dari sumber-sumber primernya, yaitual-Quran dan hadis secara tafshîlî (rinci). Dalam perspektif ini, fikih sebetulnya tidak hanya sekedar ilmu tentang hukum-hukum syar iyyah yang diperoleh melalui proses istidlâl, tetapi hukum-hukum itu sendiri kerapkali disebut fikih. ${ }^{2}$

Salah satu kritik yang diarahkan kepada produk hukum fikih adalah adanya bias gender dan ketidakadilan gender. ${ }^{3}$ Sesuatu perspektif dipandang bias gender atau ketidakadilan gender

${ }^{1}$ Muhammad Abû Zahrah, Ushûl al-Fiqh, (Mesir: Dâr al-Fikr al-'Arabî, t. th.), h. 56; Saifuddîn al-'Âmidî, Al-Ihkâm fî Ushûl al- Ahkâm, Jilid I (Kairo: Mu’assasahalHalabî, 1967), h. 8.

${ }^{2}$ sofyan a.p. kau, zulkarnain suleman, wacana non dominan: menghadirkan fikih alternatif yang berkeadilan gender, Jurnal Al-UlumVolume. 13 Nomor 2, Desember 2013Hal 245-274

${ }^{3}$ Gender adalah konsep yang menunjuk kepada sistem peranan dan hubungan antara perempuan yang tidak ditentukan oleh perbedaan biologis, tetapi ditentukan oleh lingkungan sosial, politik, ekonomi dan budaya. Akif Khilmiyah, MenataUlang Keluarga Sakinah, Keadilan Sosial dan Humanisasi Mulai dari Rumah (Surakarta: Pondok Edukasi, 2003), h. 9. jika ia termanifestasikan dalam lima bentuk, yaitu:

1. Burden; perempuan menanggung beban kerja domestik lebih banyak dan lebih lama dari laki-laki.

2. Subordinasi; adanya anggapan rendah (menomorduakan) terhadap perempuan dalam segala bidang (pendidikan, ekonomi, politik).

3. Marginalisasi; adanya proses pemiskinan terhadap perempuan karena tidak dilibatkan dalam pengambilan keputusan dalam urusan-urusan penting yang terkait dengan ekonomi keluarga.

4. Stereotype; adanya pelabelan negatif terhadap perempuan karena dianggap sebagai pencari nafkah tambahan.

5. Violence, adanya tindak kekerasan baik fisik maupun psikis terhadap perempuan karena anggapan suami sebagai penguasa tunggal dalam rumah tangga. ${ }^{4}$

Umat Islam hampir sepakat bahwa ijtihad dalam arti pembaharuan hukum Islam adalah suatu kebutuhan dasar, baik ketika Rasul masih hidup maupun setelah Rasul tiada.Sebab alQur'an dan Hadis mesti mempunyai aturan yang bersifat hukum, namun jumlahnya amat sedikit dibandingkan dengan begitu banyaknya persoalan social manusia yang memerlukan ketentuan hukum. ${ }^{5}$

\footnotetext{
${ }^{4}$ Mansur Fakih, Analisis Gender dan Transformasi Sosial, (Yogyakarta: Pustaka Pelajar, 1996), h. 15.

${ }_{5}^{5}$ Penelitian Abdul Wahab Khallaf, pakarushul fiqh, mengenai ayat-ayat hukum menjelaskan bahwa jumlah ayat-ayat Al-Qur'an yang berisi ketentuan hukum secara tegas hanya sekitar 5,8\% atau sebanyak 368 ayat saja, sedangkan jumlah yang terbesar justru berisi niali-nilai universal, seperti keadilan, cinta kasih, kedamaian, kebebasan yang kesemuanya merupakan pesan-pesan moral keagamaan yang dapat dijadikan pedoman dalam kehidupan bermasyarakat. Lihat Abdul Wahab Khallaf, 'ilm Ushu Al-Fiqh (Kairo, 1956), cet. VII, h. 34-35, lihat juga Siti Musdah Mulia, Islam dan Inspirasi Kesetaraan Gender, (Yogyakarta: Kibar Press, 2007), h. 109
} 
Redaksi ayat al-Qur'an tetap dan berlaku sepanjang zaman namun interpretasinya dapat berubah sesuai dengan tuntutan problem masyarakat. Apalagi produk hukum Islam yang notabene merupakan interpretasi ulama di masa tertentu yang dirumuskan dalam menjawabkan problem pada masanya. Hal ini tidak berarti, alQur'an dan Hadis mengekor kepada zaman tetapi dapat bermakna al-Qur'an dan Hadis memberikan solusi terbaik atas problem yang dihadapi manusia setiap zaman. Untuk itu, perlu upaya untuk reinterpetasi terhadap dalil-dalil yang dianggap bias gender dan telah membentuk image negatif terhadap perempuan, di antaranya:

Image perempuan separuh dari harga lakilaki dan sebagai objek laki-laki dapat ditemukan dalam berbagai ketentuan Hukum Islam yang tertuang dalam kitab fikih di berbagai mazhab, di antaranya:

1. Harga kesaksian dua orang perempuan sederajat dengan nilai kesaksian satu orang laki-laki. ${ }^{6} \quad$ Dalil yang digunakan untuk ketentuan tersebut yakni firman Allah Q.S. al-Baqarah: 282

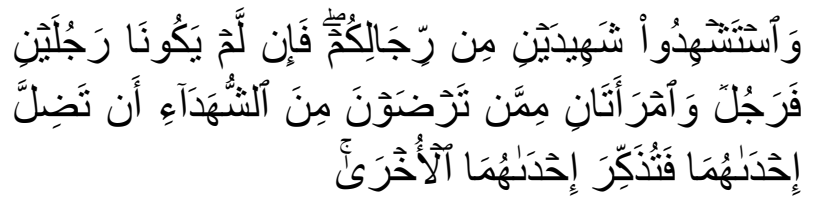

..Dan persaksikanlah dengan dua orang saksi dari orang-orang lelakidiantaramu). Jika tak ada dua orang lelaki, maka (boleh) seoranglelaki dan dua orang perempuan dari saksi-saksi yang kamu ridhai,supaya jika seorang lupa maka seorang lagi mengingatkannya..

2. Bagian perempuan separuh dari bagian lakilaki dalam halkewarisan. Dalil yang

${ }^{6}$ Muh. Rusli, Muhammad Thahir, Asriadi Zainuddin Nalar Teologis dan Hukum Islam Bias Gender, Jurnal Al-Ulum (Jurnal Studi-Studi Islam) IAIN Gorontalo,ISSN 1412-0534. Volume. 13 Nomor 2, Desember 2013 digunakan untuk ketentuan tersebut yakni firman Allah:QS.. al-Nisa: 11

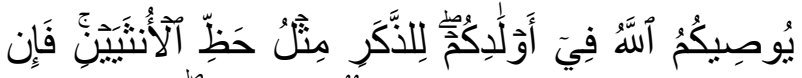

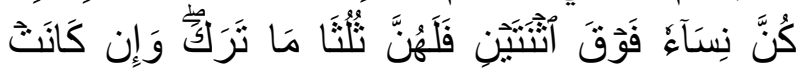

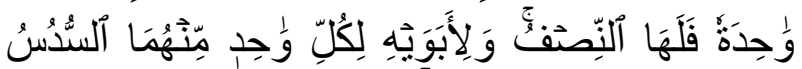

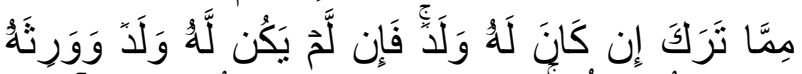

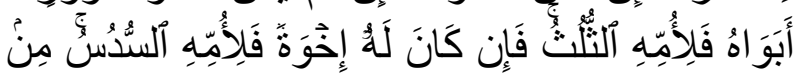

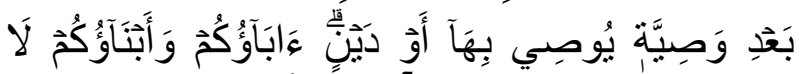

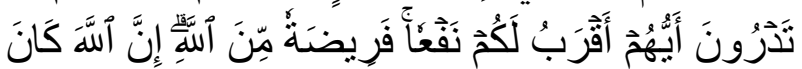

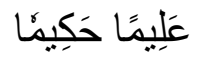

"Allah mensyari'atkan bagimu tentang (pembagian pusaka untuk anak-anakmu. yaitu : bahagian seorang anak lelaki sama dengan bahagian dua orang anak perempuan; dan jika anak itu semuanya perempuan lebih dari dua, maka bagi mereka dua pertiga dari harta yang ditinggalkan; jika anak perempuan itu seorang saja, Maka ia memperoleh separo harta. dan untuk dua orang ibu-bapa, bagi masingmasingnya seperenam dari harta yang ditinggalkan, jika yang meninggal itu mempunyai anak; jika orang yang meninggal tidak mempunyai anak dan ia diwarisi oleh ibubapanya (saja), maka ibunya mendapat sepertiga; jika yang meninggal itu mempunyai beberapa saudara, maka ibunya mendapat seperenam. (pembagian-pembagian tersebut di atas) sesudah dipenuhi wasiat yang ia buat atau (dan) sesudah dibayar hutangnya. (tentang) orang tuamu dan anak-anakmu, kamu tidak mengetahui siapa di antara mereka yang lebih dekat (banyak) manfaatnya bagimu. Ini adalah ketetapan dari Allah. Sesungguhnya Allah Maha Mengetahui lagi Maha Bijaksana.

Baik para mufassir maupun feminis Muslim sepakat menyatakan bahwa formula kesaksian 1: 2 (satu laki-laki duaperempuan) dan formula kewarisan 2: 1 (bagian laki-laki dua kali bagian perempuan) tidaklah bersifat diskriminatif terhadap perempuan. Menurut mereka formula 1:2 berdasarkan pertimbangan 


\section{5-182 | HARKAT: Media Komunikasi Islam Tentang Gender dan Anak, 11 (2), 2015}

pengalaman perempuan yang kurang dalam bidang bisnis (di waktu lampau). Sedangkan formula kewarisan 2:1 berdasarkan asas keadilan berimbang antara hak dan kewajiban. ${ }^{7} 2: 1$ (bagian laki-laki dua kali bagian perempuan) juga dapat dikaitkan dengan posisi laki-laki yang diberi tanggungjawab untuk menafkahi keluarganya (isteri dan anak-anaknya), sedang perempuan tidak. Kewajiban syariat tersebut telah ditetapkan, walaupun isteri mempunyai harta yang lebih banyakdari suaminya. ${ }^{8} \mathrm{Di}$ samping itu, konstruk budaya pada waktu itu menghendaki laki-laki yang mencari harta sedangkan perempuan mengurus rumah tangga. Bagian laki-laki akan digunakan sebagai modal usaha dalam membangun kehidupan keluarganya. Jadi bagian laki-laki meskipun besar bila dibandingkan perempuan, namun bagian tersebut masih dalam jumlah hitungan kotor. Belum lagi mereka harus memberikan mahar kepada perempuan bila ia melamarnya.

3. Setiap orang tua dianjurkan untuk menyembelih hewan akikah untuk anaknya yang baru dilahirkan. Bagi anak laki-laki dua ekor kambing, dan untuk perempuan cukup seekor saja. Menyikapi ketentuan di atas, Selain kaitannya dengan ta'abbudi, ketentuan tersebut sangat erat kaitannya dengan konstruk budaya yang melingkupinya. Laki-laki merupakan simbol kekuatan fisik dalam memperjuangkan agama Islam pada waktu itu, namun akan berbeda bilamana umat Islam telah kuat secara kuantitas dan kualitas seperti sekarang ini, maka boleh jadi jumlah hewan yang

${ }^{7}$ Yunahar Ilyas, Isu-isu Feminisme dalam Tinjauan Tafsir Al-Qur'an - Studi Kritik Terhadap Pemikiran Para Mufassir dan Feminis Muslim, Jurnal Studi Gender Yin Yang, Vol. 6 No. 1. 2004, 9.

${ }^{8}$ Sa'di Abu Habieb, Ensiklopedi Ijmak: Persepakatan Ulama dalam Hukum Islam, diterjemahkan oleh Sahat Machfudz dan Mustofa Bisri (Jakarta, Pustaka Firdaus, 1987), h. 1987. disembelih tergantung pada kemampuan orang tuanya sebagai bentuk kesyukuran atas lahirnya buah hati mereka. Boleh jadi mereka menyembelih hewan dua atau tiga ekor untuk anak perempuan begitu pula anak laki-laki. Dengan demikian, angka 1 untuk perempuan dan 2 untuk laki-laki tidak harus dimaknai bias gender, angka tersebut hanya bersifat angka standar.

4. Saat anak perempuan belum dapat makan apa-apa selain ASI, ketentuan fikih membedakan cara membersihkan benda yang terkena air kencingnya dengan kencing bayi laki-laki. Untuk kencing bayi laki-laki cukup dengan memercikan air (al-nadhh) pada benda yang terkena najis (kencing) tersebut. Menurut Imam al-Nawawî, yang dimaksud memercikannya dengan air adalah bahwa percikkan air itu merata, mengalir dan menetes kepada benda yang kena kencing, dan itu berarti tidak disyaratkan memerasnya. Ini adalah pendapat yang sahih lagi terpilih (al-shahîh al-mukhtâr). Imam al-Haramain dan para peneliti (muhaqqiq) juga berpendapat demikian. 'Sebaliknya, jika benda yang terkena najis (kencing) bayi perempuan, maka cara membersihkannya dengan mengalirkan air pada benda yang terkena kencingnya tersebut. Itu berarti, kencing anak perempuan yang membasahi pakaian harus dicuci. Perbedaan cara menyucikan benda yang terkena kencing anak kecil laki-laki dan perempuan adalah pendapat yang diperpegangi oleh kebanyakan ulama seperti Imâm al-Syâfi' î,

${ }^{9}$ Itu berarti, jika anak itu sudah makan makanan, maka cara mensucikannya tidak lagi dengan memercikkannya dengan air, akan tetapi sudah harus dicuci, tegas Qatadah. Al-Kahlânî al-Shana'ânî, Subul alSalâm, Juz I, h. -3839. 
ulama Syâfíiyyah dan Hanâbilah, dan Wahbah al-Zuhailî. ${ }^{10}$

5. Laki-laki yang berhak melamar sedangkan perempuan statusnya sebagai yang dilamar. Mahar atau mas kawin dalam tata pernikahan wajib adanya, sebagaimana Allah berfirman QS. An.Nisa ayat 4 :

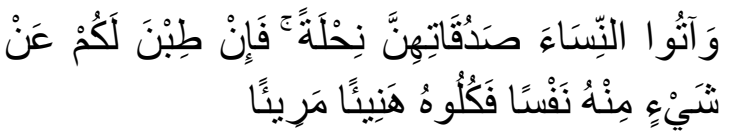

"Berikanlah maskawin (mahar) kepada perempuan (yang kamu nikahi) sebagai pemberian dengan penuh kerelaan. Kemudian jika mereka menyerahkan kepada kamu sebagian dari maskawin itu dengan senang hati, maka makanlah (ambillah) pemberian itu (sebagai makanan) yang sedap lagi baik akibatnya”.

Pada dasarnya laki-laki berhak melamar dan perempuan sebagai yang dilamar tidaklah dimaknai bias gender. Justru sebaliknya melamar merupakan bentuk penghargaan kepada perempuan dan keluarganya. Di samping itu, perempuan memiliki hak untuk menerima atau menolak lamaran seorang laki-laki.Kalaupun hari ini masih ada yang dipaksa nikah oleh orang tuanya maka kesalahannya bukan pada ajaran agama, tetapi lebih pada kekeliruan orang dalam memahami ajaran agama.

6. Apabila nyawa seorang melayang (terbunuh), keluarganya berhak menuntut ganti rugi terhadap si pembunuh dan atau keluarganya. Ganti rugi ini disebut diyah. Untuk nyawa seorang laki-laki, diyah-nya bisa mencapai 100 ekor onta, sedang untuk nyawa seorang perempuan hanya

${ }^{10}$ Ahmad al-Syirbâsyî, Yas'alûnaka fî al-Dîn wa alDunyâ, Vol I, (Beirût: Dâr al-Jail, 1995), h. 30; Wahbah al-Zuhailî, al-Fiqh al-Islâmî wa Adillatuhu, (Damaskus: Dâr al-Fikr, 1989), h. 159. separohnya, 50 ekor saja. Ketentuan ini, didasarkan pada hadis Nabi yang diriwayatkan oleh Baihaki, bahwa: "Diyah perempuan separoh diyah laki-laki”.

Bila melihat derajat perempuan waktu itu (masa Nabi), maka jumlah 50 ekor unta pada dasarnya telah cukup adil. Setidaknya jumlah tersebut menunjukkan adanya penghargaan kepada perempuan di mana sebelumnya tidak berharga sama sekali. Disamping itu, model ganti rugi nyawa tersebut kini mulai ditinggalkan dengan adanya hukum negara yang mengatur setiap tindak kejahatan sebagaimana yang terjadi di Indonesia. Sekalipun ia memberikan sejumlah uang duka kepada keluarga si korban atau menyekolahkan anak-anak yang ditinggalkan si korban, tetap saja pelaku kejahatan mengikuti proses hukum pidana yang berlaku.

7. Perempuan yang hendak dinikahi boleh dilihat-lihat bagian tubuhnya, atau diinspeksi oleh lelaki (calon suami), seperti layaknya barang yang ada dalam proses penawaran. Pada dasarnya tujuan inspeksi yang dilakukan oleh calon suami tidaklah bias gender sebab tidak melampaui aturan norma kesopanan dan biasanya diwakilkan kepada keluarganya (perempuan).

Model inspeksi seperti ini juga sudah jarang ditemukan di kalangan masyarakat sebab mereka kawin atas dasar suka sama suka dan sudah saling mengenal kepribadian satu sama lain sebelum akhirnya memutuskan untuk berumah tangga.

8. Keharusan agama atas perempuan untuk memenuhi permintaan suami, termasuk untuk hal-hal yang menurut agama sunnat dilakukan. Misalnya permintaan suami agar isterinya tidak lagi membiarkan puasa Senin atau Kamis, terutama permintaan yang berkaitan dengan pemenuhan hasrat seksual, anjuran agama sangat kuat agar si isteri 
mengabulkannya. Ada hadis yang menyatakan:

"Isteri siapa yang menolak permintaan kumpul sang suami lalu suami pun kecewa, maka atas perempuan itu kutukan dari malaikatsampai pagi hari tiba”."

Guna membangun keluarga sakinah, mawaddah, wa rahmah tentu dibutuhkan saling pengertian antara suami istri. Untuk itu, segalanya harus didiskusikan termasuk dalam hal beribadah kepada Allah (baca: puasa). Hadis di atas menekankan pada bagaimana membangun komunikasi yang baik dalam rumah tangga sehingga tercipta saling menghargai dan menghormati satu sama lain. Dengan demikian, hadis tersebut tidaklah bias gender.

9. Larangan perempuan (isteri) untuk keluar rumah tanpa seizin laki-laki (suami). Dasar penekanannya pada kata "izin suami“. Hal ini dimaksudkan agar terhindar dari fitrah yang dapat menyebabkan hancurnya sebuah rumah tangga. Larangan keluar rumah bagi perempuan dalam konteks sejarah $\mathrm{Nabi}$ memang dapat dibenarkan, sebab kaum kafir Quraisy seringkali mengganggu mereka.

Berbeda dengan konteks kekinian dimana kondisi lingkungan telah aman dan perempuan memiliki pergaulan yang luas. Intinya adalah izin tetap dibutuhkan meskipun sudah era modern, hal ini dimaksudkan sebagai bentuk penghargaan istri kepada suami. Hal yang sama juga dilakukan oleh suami ketika ingin keluar rumah harus minta izin kepada istrinya. Kalaupun masih ada yang melarang istrinya keluar rumah barangkali karena ia masih takut istrinya diganggu atau menghendaki

${ }^{11}$ Hadis riwayat $\mathrm{Ab}-$ Hurayrah, lihat al-Qas-allan, Jawahir al-Bukhri (Mesir: t.th.), h. 338. agar istrinya fokus pada pembinaan anak. Boleh juga karena konstruk budaya yang bias gender dan menganggap mereka mahluk lemah yang perlu dijaga dan dilindungi.

10. Dalam fikih salat, perempuan tidak diperbolehkan menjadi imam. Seluruh ahli fikih sepakat bahwa perempuan dan banci tidak sah menjadi imam bagi orang lakilaki. ${ }^{12}$ Dalam mazhab Mâlikî perempuan tidak sah menjadi imam walaupun untuk mengimami sesamanya. ${ }^{13}$ Sebab, syarat imam salat jama'ah adalah laki-laki. Demikian pendapat mazhab Syâfi' î, Hanbalî dan Mâlikî. Karena itu, mazhab yang disebut terakhir mengharuskan pengulangan kembali salat yang bermakmum kepada imam perempuan, meskipun di antara makmum itu ada laki-laki, perempuan atau bukan. ${ }^{14}$

11. Sementara dalam fikih puasa, kebanyakan ulama berpendapat bahwa seorang istri tidak diperkenankan untuk berpuasa sunat kecuali atas izin suami. Perkenan izin tersebut dikarenakan keberadaan suami di rumah dan hanya berlaku untuk puasa sunat.

Adapun untuk puasa wajib seperti puasa Ramadhan tidak diperlukan izin suami. Sebagian lagi berpendapat, larangan puasa sunat istri, bukan disebabkan tanpa izin suami, melainkan kelalaian kewajiban istri terhadap suami ketika sedang berpuasa. Itu berarti keberadaan suami di rumah merupakan kausa legis. Tegasnya,

${ }^{12}$ Muhammad Ibrâhim Jannatî, Durûs fî al-Fiqh alMuqâran, Terj. Ibnu Alwi Bafaqih, (et. al.). Fiqh Perbandingan Lima Mazhab, Jilid I. (Jakarta: Cahaya, 2007), h. 481.

${ }^{13}$ Muhammad Jawad Mughniyah, Al-Fiqh 'alâ alMadzâhib al-Khamsah, terj. Masykur A.B., Afif Muhammad dan Idrus Al-Kaff, Fiqih Lima Mazhab. Cet ke-25; (Jakarta: Lentera, 2010), h. 136.

${ }^{14}$ A'mur Daud, Fiqh Wanita tentang Salat, (Jakarta: Media Dakwah Indonesia, 1995), h. 113. 
keniscayaan izin suami, berkaitan erat dengan kewajiban istri dan hak suami. Kehadiran suami di rumah membutuhkan pemenuhan haknya.

Kebutuhan biologis adalah salah satu hak suami. Kebutuhan ini tidak akan terpenuhi saat mana istri sedang berpuasa. Menurut Syafiq Hasyim, ajaran ini bersumber dari aturan umum Islam tentang etika keluarga bahwa suami adalah pemimpin kaum perempuan, sebagaimana disinyalir oleh surat al-Nisâ' ayat 34. Dalam sebuah hadis juga dinyatakan bahwa suami merupakan pemimpin istri dan dia akan dimintai pertanggungjawaban atas istri tersebut. $^{15}$

Pendapat di atas dalam perspektif gender, dinilai bias gender. Sebab pendapat tersebut menunjukkan otoritas suami atas istri, sehingga untuk pelaksanaan ibadah pun meniscayakan izin suami. Sedangkan Islam mengajarkan otonomi perempuan berbuat amal salehsecara mandiri. Sementara fikih belum menyediakan ruang kemandirian atas perempuan.

12. Dalam perwalian dan persaksian pernikahan. Bahwa salah satu syarat seorang wali dalam pernikahan adalah laki-laki. ${ }^{16}$ Karena itu, perempuan tidak boleh menjadi wali baik atas orang lain maupun atas dirinya sendiri. Itu berarti, ia tidak boleh menikah tanpa wali atau menikahkan dirinya. Dengan kata lain, perempuan tidak boleh menikahkan dirinya. Ia harus dinikahkan oleh walinya. ${ }^{17}$ Tegasnya, perempuan membutuhkan wali dalam perkawinan. Tanpa wali, perkawinan tidak sah.

${ }^{15}$ Syafiq Hasyim, Hal-Hal Yang Tak Terpikirkan tentang Isu-Isu Keperempuanan Dalam Islam, (Bandung: Mizan, 2001), h. 221-222.

${ }^{16}$ M. S. Abdul Halim, Fikih Madrasah Aliyah Kelas 2 (Jakarta: Pt Listafariska Putra, 2005), h. 62.

${ }^{17}$ Sayyid Sâbiq, Fiqh al-Sunnah, Jilid II (Beirût: Dâr al-Fikr, 1983), h. 125.
13. Adapun dalam hal kesaksian, mayoritas ulama sepakat bahwa kesaksian dalam pernikahan merupakan rukun dan keharusan. Tanpa adanya kesaksian, pernikahan dinilai tidak sah. ${ }^{18}$ Tidak semua orang dapat menjadi saksi, kecuali yang memenuhi syarat. Satu di antaranya adalah dua orang laki-laki. Itu berarti, kesaksian perempuan dipandang tidak sah. ${ }^{19}$ Dengan kata lain, pernikahan dipandang sah, jika saksinya terdiri atas dua orang saksi laki-laki. Bila perempuan menjadi saksi, maka kesaksiannya dinilai batal atau tidak sah. Dalam mazhab Syâfî̀̂, Mâlikî, dan salah satu riwayat dari mazhab Hanbalî, tidak menerima saksi perempuan dalam pernikahan, talak dan rujuk secara mutlak baik disertai laki-laki maupun tidak disertai laki-laki. ${ }^{20}$ Al-Dimyathî juga menolak saksi perempuan dalam pernikahan walaupun jumlahnya dua orang dan disertai laki-laki. Alasannya karena pernikahan merupakan akad yang bukan harta, dan biasanya dapat dilihat oleh kaum laki-laki. ${ }^{21}$

14. Dalam aspek keterlibatan dalam ruang publik. Mayoritas ulama berpendapat bahwa wanita tidak boleh menjadi pemimpin publik. Sebab hak kepemimpinan ada pada kaum lelaki karena kelebihan mereka atas kaum wanita. Kelebihan tersebut terletak pada akal, keteguhan hati, kemauan keras, kekuatan fisik, dan keberanian atau ketangkasan, ilmu pengetahuan (al-'ilm) dan kemampuan fisik (al-qudrah).

Akal dan pengetahuan laki-laki, menurutnya, melebihi akal dan pengetahuan perempuan. Oleh karena itu, untuk

\footnotetext{
${ }^{18}$ M. S. Abdul Halim, Fikih Madrasah Aliyah Kelas 2 (Jakarta: Pt Listafariska Putra, 2005), h. 61.

${ }^{19}$ Ibid.

${ }^{20}$ Abdurrahmân al-Jazîrî, al-Fiqh 'ala al-Madzâhib al-Arba'ah, Jilid IV (Beirût: Dâr al-Fikr, 1970), h. 23-24.

${ }^{21}$ Imam Mâlik, al-Mudawwanah al-Kubrâ, Jilid XIII (Beirût: Dâr al-Fikr, t. th),h.161.
} 
pekerjaan-pekerjaan keras, laki-laki lebih pantas. Bahkan kenabian, keulamaan, kepemimpinan besar yang bersifat publik dan jihad hanya diberikan kepada laki-laki. ${ }^{22}$ Bahkan menurut al-Âlûsî (w.1270) kelebihan kaum pria bersifat wahbî (pemberian Tuhan) sehingga meskipun ayat tidak mengungkapkan secara langsung persoalan kelebihan laki-laki, itu dikarenakan kelebihan laki-laki atas perempuan sudah sangat jelas sehingga tidak memerlukan lagi penjelasan secara rinci.

Menyikapi berbagai macam ketentuan di atas, tentu saja kita harus membuka kembali lembaran sejarah awal turunnya ayat dengan kondisi sosial budaya yang melingkupinya. Sebab-sebab turunnya ayat dapat menjadi dasar pemahaman bahwa al-Qur'an tidak turun di ruang hampa budaya tetapi ia turun dalam masyarakat yang berbudaya yang butuh proses untuk mencapai apa yang menjadi tujuan utama diturunkannya al-Qur'an.

Derajat perempuan diangkat oleh $\mathrm{Nabi}$ tentu saja tidak serta merta langsung sejajar dengan derajat laki-laki. Perlu berbagai macam pertimbangan sebab sebelumnya perempuan tidak memiliki derajat sama sekali. Hal ini dilambangkan dengan penguburan anak perempuan hidup-hidup karena dianggap hanya menjadi aib keluarga.

Di samping itu, jika perempuan langsung memiliki kedudukan seperti laki-laki maka orang-orang Quraisy pada waktu itu akan syok dan menganggap hal tersebut sebagai ancaman. Penolakannya kepada Islam tidak lagi karena ia ragu kepada Nabi Muhammad dan agama yang dibawanya tetapi lebih pada rasa takut

${ }^{22}$ Al-Zamakhsyârî, Al-Kasysyâf, h. 523-524; Abû alFadhl Syihâb al-Dîn al- Sayyid Mahmûd Afandî al-Âlûsî al-Baghdâdî, Rûh al-Ma'ânî fî̀ Tafsîr al-Qur'ân al-'Azhîm wa al-Sab’i al-Matsânî, Jilid III, (Beirût: Dâr al-Fikr, t.th.), h. 2 ; Muhammad Husain al-Thabâthabâ'î, Al-Mîzân fî̀ Tafsîr al-Qur'ân, Jilid II, (Beirût: sMu'assasah al-'Alam li Mathbû'at, 1991), h. 351. kepentingannya terancam sebagaimana terancamnya ia ketika Nabi mengajarkan bahwa manusia sama dihadapan Allah. Mereka takut budak-budak mereka yang selama ini patuh atas apa yang diperintahkan akan memberontak dan memerdekakan diri. Demikian halnya jika perempuan diberi ruang untuk menduduki posisi penting maka kepentingan mereka akan terusik.

Nabi paham betul bahwa secara psikologis mereka akan syok bila tidak dilakukan secara bertahap. Barangkali karena itu pulalah perintah dalam al-Qur'an juga bertahap dalam mengangkat derajat perempuan.

Dalam kasus yang lain misalnya ditemukan bahwa larangan terhadap khamar atau minuman keras juga dilakukan secara bertahap. Misalnya larangan meminum khamar ketika hendak shalat, selanjutnya pada tahap terakhir sudah melarang khamar sama sekali.

Dibutuhkan proses yang panjang untuk sampai pada apa yang menjadi tujuan diturunkannya al-Qur'an. Di samping itu, tidak dapat dinafikan bahwa banyak juga ayat alQur'an dan hadis yang menekankan pentingnya kemitraan laki-laki dan perempuan untuk bekerjasa sama dalam berbagai bidang.

a. Allah berfirman: Q.S. al-Taubah:71

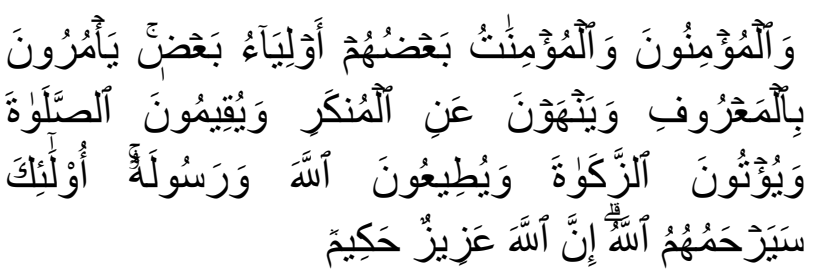

"Dan orang-orang yang beriman, laki-laki dan perempuan, sebahagian mereka (adalah) menjadi penolong bagi sebahagian yang lain. Mereka menyuruh (mengerjakan) yang ma'ruf, mencegah dari yang munkar, mendirikan shalat, menunaikan zakat dan mereka taat pada Allah dan Rasul-Nya.Mereka itu akan diberi rahmat oleh Allah; Sesungguhnya Allah Maha Perkasa lagi Maha Bijaksana”. 
b. Firman Allah swt. Q. S. Âli 'Imrân:195

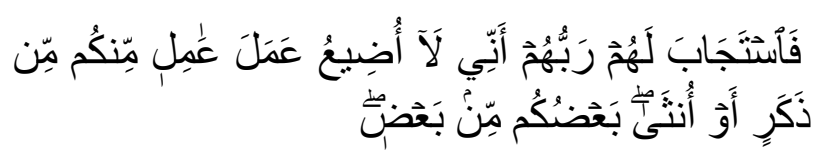

"Maka Tuhan mereka memperkenankan permohonannya (dengan berfirman): "Sesungguhnya Aku tidak menyia-nyiakan amal orang-orang yang beramal di antara kamu, baik laki-laki atau perempuan, (karena) sebagian kamu adalah turunan dari sebagian yang lain”.

c. Firman Allah swt. Q. S. al-Hijr: 26

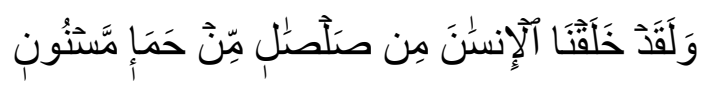

"Dan Sesungguhnya Kami telah menciptakan manusia (Adam) dari tanah liat kering (yang berasal) dari lumpur hitam yang diberi bentuk".

d. Firman Allah Q. S. al-Hujarât/49:13

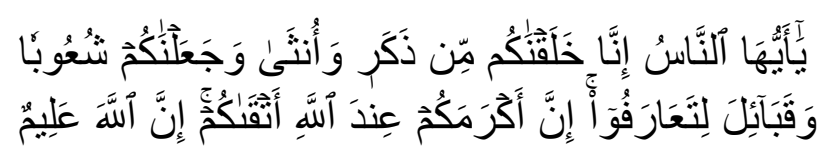

خَبِّن

"Hai manusia, sesungguhnya Kami menciptakan kamu dari seorang laki-laki dan seorang perempuan dan menjadikan kamu berbangsa-bangsa dan bersuku-suku supaya kamu saling kenal-mengenal. Sesungguhnya orang yang paling mulia di antara kamu di sisi Allah ialah orang yang paling taqwa di antara kamu. Sesungguhnya Allah Maha mengetahui lagi Maha Mengenal”.

Dengan demikian, Allah akan menerima ibadah hambanya tanpa melihat jenis kelaminnya. Adapun yang membedakan keduanya adalah kualitas atau tingkat ketakwaannya. Di samping itu, atas dasar penciptaan yang sama yakni sama-sama dari saripati tanah, maka Allah menghendaki agar manusia mau bekerja sama, saling bahu membahu, tolong menolong dalam kebaikan.
Jika manusia sama di hadapan Allah maka seharusnya manusia tidak saling menindas satu sama lain hanya karena perbedaan jenis kelamin. Bahkan, jika kita mencermati beberapa hadis Nabi di mana dalam kasus tertentu perempuan memiliki keistimewaan seperti kedudukan isteri terhadap anak-anaknya. Sabda Rasul saw. Berkata: al- jannat tahta akdamil ummahat (Surga itu di bawah telapak kaki ibu). Dengan demikian, penghormatan yang dipersembahkan kepada ibu sangat tinggi tanpa menafikan ayah tentunya..

\section{PENUTUP}

Al-Qur'an berlaku sepanjang zaman, namun al-Qur'an tidak terlepas dari realitas sosial budaya yang melingkupinya. Membaca alQur'an tidak cukup dengan menerjemahkan secara tekstual, sebab persoalan yang dihadapi oleh umat Islam pada masa Nabi lebih ringan bila dibandingkan dengan persoalan umat Islam kekinian dan masa yang akan datang. Jika alQur'an, Hadis, dan produk Hukum Islam tidak mampu menjadi solusi bagi problem umat maka al-Qur'an tetap ada dalam kehidupan manusia tetapi ia hanya menjadi bacaan seremonial belaka. Setiap interpretasi terhadap makna alQur'an tidak seharusnya dituding sebagai bid'ah apalagi kafir hanya karena berbeda pemahaman dengan mufassir terdahulu. Tidak terkecuali dalam memahami wacana gender. Untuk itu, perlu interpretasi secara kontekstual dengan mempertimbangkan kondisi kekinian dan prinsip kemaslahatan bersama.

Dengan demikian, jauh sebelum Barat mengumandangkan wacana gender, Nabi Muhammad telah membawa ajaran persamaan derajat di hadapan Allah, tanpa mengenal perbedaan jenis kelamin. Allah menjanjikan pahala kepada seluruh manusia yang bertakwakepada-Nya. Untuk itu, Allah menghendaki adanya kerjasama antarmanusia untuk mencapai kebahagiaan hidup di dunia dan 


\section{1 -182 | HARKAT: Media Komunikasi Islam Tentang Gender dan Anak, 11 (2), 2015}

akhirat. Hanya saja, dibutuhkan perjuangan dan proses yang panjang oleh Nabi dan sahabatnya serta umat Islam pada umumnya untuk merubah pemahaman budaya yang deskriminatif terhadap perempuan, hal tersebut disebabkan perilaku bias gender telah terbangun dan mapan melalui institusi sekolah, keluarga, dan masyarakat.

Tentu saja, upaya tersebut seyogyanya diwacanakan terus menerus sehingga apa yang menjadi tujuan diturunkannya al-Qur'an bahwa manusia sama di hadapan Allah dapat terwujud di kemudian hari. Amin ya rabbalalamin.

\section{DAFTAR PUSTAKA}

A'mur Daud, Fiqh Wanita tentang Salat, Jakarta: Media Dakwah Indonesia, 1995

Abdul Wahab Khallaf, 'ilm Ushu Al-Fiqh Kairo, 1956

Abdurrahmân al-Jazîrî, al-Fiqh 'ala al-Madzâhib al-Arba'ah, Jilid IV Beirût: Dâr al-Fikr, 1970

Abû al-Fadhl Syihâb al-Dîn al- Sayyid Mahmûd Afandî al-Âlûsî al-Baghdâdî, Rûh alMa'ânî fî Tafsîr al-Qur'ân al-'Azhîm wa alSab’i al-Matsânî, Jilid III, Beirût: Dâr alFikr, t.th

Ahmad al-Syirbâsyî, Yas'alûnaka fî al-Dîn wa alDunyâ, Vol I, (Beirût: Dâr al-Jail, 1995), h. 30; Wahbah al-Zuhailî, al-Fiqh al-Islâmî wa Adillatuhu, Damaskus: Dâr al-Fikr, 1989

Akif Khilmiyah, MenataUlang Keluarga Sakinah, Keadilan Sosial dan Humanisasi Mulai dari Rumah, Surakarta: Pondok Edukasi, 2003

Imam Mâlik, al-Mudawwanah al-Kubrâ, Jilid XIII Beirût: Dâr al-Fikr, t. th

Kahlânî al-Shana'ânî, Subul al-Salâm, Juz I, h. 3839.
Mansur Fakih, Analisis Gender dan Transformasi Sosial, Yogyakarta: Pustaka Pelajar, 1996

Muh. Rusli, Muhammad Thahir, Asriadi Zainuddin Nalar Teologis dan Hukum Islam Bias Gender, Jurnal Al-Ulum (Jurnal Studi-Studi Islam) IAIN Gorontalo,ISSN 1412-0534. Volume. 13 Nomor 2, Desember 2013

Muhammad Abû Zahrah, Ushûl al-Fiqh, Mesir: Dâr al-Fikr al-'Arabî, t. th

Muhammad Husain al-Thabâthabâ'î, Al-Mîzân fî Tafsîr al-Qur'ân, Jilid II, Beirût: sMu'assasah al-'Alam li Mathbû'at, 1991

Muhammad Ibrâhim Jannatî, Durûs fî̀ al-Fiqh al-Muqâran, Terj. Ibnu Alwi Bafaqih, (et. al.). Fiqh Perbandingan Lima Mazhab, Jilid I. Jakarta: Cahaya, 2007

Muhammad Jawad Mughniyah, Al-Fiqh 'alâ alMadzâhib al-Khamsah, terj. Masykur A.B., Afif Muhammad dan Idrus Al-Kaff, Fiqih Lima Mazhab. Cet ke-25; Jakarta: Lentera, 2010

Sa'di Abu Habieb, Ensiklopedi Ijmak: Persepakatan Ulama dalam Hukum Islam, diterjemahkan oleh Sahat Machfudz dan Mustofa Bisri Jakarta, Pustaka Firdaus, 1987

Saifuddîn al-'Âmidî, Al-Ihkâm fî Ushûl alAhkâm, Jilid I Kairo: Mu'assasahal-Halabî, 1967

Sayyid Sâbiq, Fiqh al-Sunnah, Jilid II Beirût: Dâr al-Fikr, 1983

Siti Musdah Mulia, Islam dan Inspirasi Kesetaraan Gender, Yogyakarta: Kibar Press, 2007

Syafiq Hasyim, Hal-Hal Yang Tak Terpikirkan tentang Isu-Isu Keperempuanan Dalam Islam, Bandung: Mizan, 2001 
Yunahar Ilyas, Isu-isu Feminisme dalam Zamakhsyârî, Al-Kasysyâf, Hadis riwayat AbTinjauan Tafsir Al-Qur'an - Studi Kritik Hurayrah, lihat al-Qasªllan, Jawahir alTerhadap Pemikiran Para Mufassir dan Bukhri Mesir: t.th.

Feminis Muslim, sJurnal Studi Gender Yin Yang, Vol. 6 No. 1. 2004, 9. 